\title{
Role of Parents to Train the Independence of Students with Visual Impairment in Activity of Daily Living Skill
}

\author{
Asep Widijaya*; Gunarhadi; Sunardi \\ Universitas Sebelas Maret, Indonesia \\ Email: widijaya@gmail.com
}

http://dx.doi.org/10.18415/ijmmu.v6i1.501

\begin{abstract}
In general, students with visual impairment are often described as individuals with disabilities. Limitations will make they feel embarrassed, insecure and not confident. Therefore, the role of parents in the success of them is great. One effort to improve their independence is through activity of daily living (ADL) skill. ADL skills or self-care include the ability to eat, dressing, and toileting. For the sighted people, that ability is an informal ability. However, for students with visual impairment, these activities become formal learned at school. The purpose of this study is to determine the role of parents in improving their children's ADL skills at home. Because, togetherness between parents and children more done at home than at school. This research uses descriptive method with qualitative approach, which try to describe the object under study based on reality. The data collection is done by observation, interview and documentation study. Subjects in this study were 5 parents of students with visual impairment and 1 teacher. The results of the study found that parents were willing and able to train ADL skills, although not yet optimal and in accordance with the norms and practices prevailing in the community.
\end{abstract}

Keywords: Parents; Independence; Students; Visual Impairment

\section{Introduction}

Education is one form of manifestation of a dynamic human culture and full of development. In line with changes in the culture of life, change or development of education is something that must happen. Changes or improvements in education at all levels need to be continuously done to anticipate future interests.

Education that can support development in the next era is education that able to develop the potential of students. So, they are able to face and solve the problems and challenges of life it faces, now and in the future. Education must reach the potential of conscience and potential competence. Because the concept feels increasingly important when students enter life in the community and in the world of work.

Due to the national educational objectives stated in Law Number 20 Year 2003 on National Education System, Article 3 states: "National education serves to develop the ability and form the character and civilization of a dignified nation to educate the life of the nation, aims for the development of prospective participants educated to be a trusting and wise man of God Almighty, healthy, 
knowledgeable, capable, creative, independent, and being a democratic and responsible citizen. In this connection, education is expected to prepare learners to be independent without dependency on others. In fact, there are children with special needs right to get special education services. One of them is students with visual impairment.

According to Somantri (2007), people with visual impairment are individuals whose sense of vision does not function as a receiving channel of information in daily activities. Blindness can be grouped into two types, namely Totally Blind, if the eye is totally unable to receive excitatory light from the outside (visus zero), and Low Vision, the eye is still able to receive excitatory light from the outside, but sharpness more than 6 per 20, or eyes only able to read headlines on newspapers.

Independence education for students with visual impairment is a basic skill that must be possessed well. If the ability of basic independence is not mastered, then they will be difficult to develop their potential optimally.

Ayu Winda Utami Santosa and Adijanti Marheni (2013: 54-62), argue that attitudes toward selfreliance in adolescents have a positive impact on self-improvement on the environment, overcoming difficulties, stability and robust resistance to challenges and pressures. In line with the above statement, Arifah Kusumawardhani, Sri Hartati \& Imam Setyawan (2010: 252-257), explain for the purpose of selfindependence identity both physically and emotionally.

Thus, it is clear that the ability of independence is required for students with visual impairment. Because, they will not always live depending on their parents. One day they must be able to live independently in accordance with their capabilities.

Based on the above statements, it can be ascertained that students with visual impairment must also receive education, both at school, at home and in the community, according to their abilities. If learning to them is really executed and gets a positive boost from parents, then the goal of learning for independence will be achieved optimally.

One of the efforts to improve the independence ability of students with visual impairment is through Activity of Daily Living (ADL) skill. As Snell (1983) points out, the ability of self-help (selfcare) includes: 1 . The ability to eat and drink (eating), including the ability to swallow food, the ability to use a finger to hold food, the ability to use a spoon to eat, the ability to use forks to eat, and the ability to use cups/cups for drinking; 2. Dressing, such as the ability to remove trousers or skirts, wearing trousers or skirts, removing socks, wearing socks, removing cardigans, wearing cardigans, removing polo shirts, wearing polo shirts, removing shoes and wearing shoes; 3 . Using the toilet (toileting), such as the ability to identify the desire to urinate or defecate, control the desire to urinate or defecate, go to the bathroom, remove pants/ skirts, sitting on the toilet, watering toilet, wore pants/ skirts, and left the bathroom.

In line with the above statement, the mastery of activity daily living ability for students with visual impairment is very important to increase the confidence. The results of research conducted by Puguh Setiyoko, Wahyudi Hartono (2015), from the Department of Special Education of the State University of Surabaya, "In the puberty of blind children", suggests that students with visual impairment who master daily living activity will be able to enter social interaction with good, even a sense of confidence arises. Students with visual impairment who are able to dress cleanly, neatly and harmoniously will be acceptable in their social environment well.

Meanwhile, less precise parenting is often done by parents who have students with visual impairment. A great affection for the children, often forgetting parents that they must be independent of their children so that they are not always dependent on others. The role of parents is so great in helping 
children to be able to do activity of daily living in taking care of him. Parental care as home teachers is the most important thing for children's independence.

The ability of activity of daily living will be able to be mastered well by students with visual impairment, if given with appropriate and sustainable way. Giving an activity of daily living exercise should be given every day in a certain time so that they are accustomed and able to remember the order and the way given.

Based on preliminary interviews conducted by researchers with the parents of students with visual impairment in SLB A and A Ganda Binar Insan Istiqomah, Bekasi Regency, West Java Province, regarding the role of parents in establishing their children, that no parent has formally trained their child's activity of daily living skills. The problem is found that some students with visual impairment experience obstacles in doing the activity. Such as the ability to eat and drink (eating), dressing and the use of toilets (toileting). This happens because parents do not know how to practice activity of daily living skills formally in their children.

\section{Methodology}

This research uses a descriptive method. Descriptive method is an attempt to find, develop and verify the truth of an event. As proposed by Moleong L. J (1996: 6), that "Research aimed at describing or explaining something as it is. This method is done to reveal the events or descriptions of the phenomena that occur in the present. "

Descriptive research is generally done with the main purpose of describing the systematic facts and characteristics of objects or subjects are researched appropriately. The purpose of this study is to get a picture of the role of parents for the independence of students with visual impairment in SLB A and A Ganda "Binar Insan Istiqomah" in activity of daily living. Therefore, the appropriate method is descriptive method with qualitative approach.

A qualitative approach is used to express what is actually happening in the field. As Nasution (1996: 5) notes that: "A qualitative approach is essentially observing people in their environment, interacting with them trying to understand their language and interpretations of the world around them."

Qualitative approaches essentially present directly the relationship between researchers with respondents in order to solve problems in accordance with the goals to be achieved.

From the above explanation, it can be concluded that the descriptive method with qualitative approach is easy to use because there is a relationship between the researcher with the respondent and can reveal as many problems that exist in the reality.

\section{Data Analysis}

\section{Data Collection Technique}

To obtain a description of the data in accordance with the purpose of this study, researchers used several data collection techniques that are considered relevant to the research problem, including: observation, interview and documentation study.

Observations conducted by researchers to observe directly activity of daily living students visually impaired at home and at school naturally. 
Interviews were conducted on parents and teachers of students with visual impairment. So that can be known what kind of activity daily living of each student in detail. Documentation studies are conducted on program sources that include curriculum manuals, binary books, and other supporting books in schools.

\section{Data Analysis Technique}

The technique used to analyze data is induction analysis. The researcher analyzed each theme of all incoming data, with steps: 1) data reduction, 2) Display data, and 3) Taking conclusions and verifying data.

\section{Data Reduction}

At this stage the researcher chooses which data is relevant and less relevant to the purpose of the research. In this case the information from the reality as raw material is abbreviated, summarized, arranged systematically, and highlighted the important points so that more easily controlled. Information obtained in the form of interviews and observations on research subjects. The words spoken by the research subject are selected and then summarized to be simpler and more comprehensible to the researcher.

\section{Display Data}

To be able to see the whole data or certain parts of the data, then at this stage the researchers attempt to classify and present in accordance with the subject matter that begins by looking at and compare the data obtained. This is done to facilitate the researchers in obtaining conclusions from each subject, namely the results of interviews with observations and documentation then made a matrix or chart. Matrices are generated based on the results of data that have been obtained in the reality without manipulating the data, but the data obtained in accordance with what is and happen in reality.

\section{Conclusion and Verification of Data}

This activity is intended to find the meaning of data collected by looking for relations, similarities and differences. The conclusion is done by comparing the conformity of subject statement with activity of daily living or students with visual impairment through interview result, observation and documentation study.

\section{Research Instruments}

In descriptive research with qualitative approach, which becomes an important instrument of research is the researcher himself. This means that the researcher is a planner, executor, data collector, analyser, data interpreter, and conclusion maker. The existence of researchers as an instrument is the main data gathering tool. This is done because in descriptive research with a qualitative approach the researcher is the main instrument that can examine and interpret various circumstances and simultaneously make adjustments to the reality that occurred. In addition, researchers as an instrument can establish a direct relationship with the subject and other objects and understand the links that exist. The main data in 
qualitative research is in the form of words and actions, the rest is additional data such as documents to get a picture of data in accordance with research objectives.

\section{Research Subject}

In this study, the subjects of the study were 5 parents of students with visual impairment and 1 teacher at SLB A and A Ganda "Binar Insan Istiqomah", as listed in the Table 1.

Table 1 Subjects of the study which include students' parents and a teacher at SLB A and A Ganda "Binar Insan Istiqomah

\begin{tabular}{|c|c|c|c|}
\hline No. & Name & Age & Description \\
\hline 1 & Mrs. De & 38 & $\begin{array}{l}\text { Parents of students } \\
\text { named Sep. }\end{array}$ \\
\hline 2 & Mrs. Ri & 48 & $\begin{array}{l}\text { Parents of students } \\
\text { named Sub. }\end{array}$ \\
\hline 3 & Mrs. Ho & 35 & $\begin{array}{l}\text { Parents of students } \\
\text { named Sof. }\end{array}$ \\
\hline 4 & Mrs. Su & 36 & $\begin{array}{l}\text { Parents of students } \\
\text { named Ri. }\end{array}$ \\
\hline 5 & Mrs. sum & 39 & $\begin{array}{l}\text { Parents of students } \\
\text { named Tas. }\end{array}$ \\
\hline 6 & Ms. Ya & 34 & Teacher \\
\hline
\end{tabular}

\section{Discussion}

\section{Results}

In general, parents of students with visual impairment in SLB A and A Ganda "Binar Insan Istiqomah" willing and able to train the skills of activity of daily living for their children. Although from the aspects of eating, dressing and toileting, there are parents who have difficulty in teaching the ability of the 3 aspects of it formally or normatively. Parents train their children based on life experiences, cultures and customs that prevail in their family or place of origin. So, the habits that apply in the family or the environment where they lived greatly affect the habits undertaken by their children.

In addition, the role of teachers is also crucial to the success of the program. Parents and teachers work together to practice activity of daily living skills in accordance with applicable guidelines and curricula. So that the implementation of training at home and at school can run well.

Parents want to invest their time to train their children with patient and love regularly and naturally. With the hope that the skills of activity of daily living can be a habit for their children someday. And as a result, the independence of them increases and minimizes dependence on others. In addition, they can also meet personal needs, and complete the basic tasks efficiently in dealing with the environment and surrounding communities.

However, viewed from the aspect of eating, dressing and toileting formally, there are still parents of students with visual impairment who have difficulty in some sub aspect. This is caused by certain obstacles in the children. Such as motor obstacles, behavior, lack of motivation and laziness. For that, then parents need to synergize positively with teachers at school to jointly create programs that suit the 
conditions, needs and abilities of their children. So that they are expected to be independent and no longer dependent on parents, family and society.

From the result of observation, interview and documentation study, it produces several criteria of training format of activity of daily living skill for students with visual impairment, including:

1. Activity skills training materials of daily living should be given in accordance with the conditions, needs and abilities of children gradually.

2. Selecting a variety of media, so that children are more interested and motivated in carrying out the exercise.

3. Innovate in choosing a method, to make it more interesting and fun.

4. Set a flexible training time and tailored to the children's natural willingness and condition. Because this will provide motivation and support efforts habituation

\section{Recommendation}

Based on the reality in reality about the role of parents in training activity of daily living skills for students with visual impairment, there are still subjects who have difficulty in implementing the above three aspects. To overcome this, the researcher gives the following recommendations:

\subsection{For Parents}

Based on the facts encountered in reality, there are still parents of students with visual impairment who help some or all of their children's needs. Parents assume that practicing skills in activity of daily living is time consuming and impractical. Excessive love or even less care makes parents reluctant to train the independence of their children. So, the activity of daily living skills that should be a daily routine, considered only a waste of time. In addition, parents consider the activity of daily living skills will automatically be controlled by their children. In fact, the progress and development of children cannot be separated from the attention, support and role of parents. For that, parents are expected to work with teachers in an effort to improve the ability of children.

\subsection{For Teachers}

The activity of daily living skills consisting of the aspects of the ability to eat and drink, dress and use the toilet is the basic ability of independence that must be owned by students with visual impairment. As one effort to increase the independence for the provision of living in the community. In order for the program to run in accordance with the goals to be achieved, parents and teachers are expected to synergize in improving the skills of basic skills. In addition, parents and teachers can also discuss and explore new experiences that are appropriate to the children's developmental tasks. Thus, it is expected that their ability can continue to increase in accordance with their potential.

\subsection{For Further Researchers}


The results of this study only discuss the role of parents of students with visual impairment in training activities of daily living skills that include aspects of eating and drinking, dressing and using the toilet. While in the routine of daily activities, there are still many problems faced by students with visual impairment. Like difficulties in orientation and mobility, socializing and communicating with the environment and society. Therefore, further investigators can raise these issues. So, it is expected that they can be independent, confident, and can develop all the potential they have optimally.

\section{Conclusion}

Education is the main capital that must be owned by everyone, not the exception for students with visual impairment. They have limited ability, unlike other children in general. With the education, the students with visual impairment can develop their capabilities optimally so that they are able to deal with various problems related to their needs.

One of the important lessons for students with visual impairment is the effort to improve the skill of activity of daily living. Because, basically this ability is an integral part of everyone's life. This activity has become a daily routine that began to wake up in the morning to sleep back at night.

Activity of daily living becomes difficult for students with visual impairment because of the visual barrier that they have. They cannot imitate activities done by others around them. The difficulties will also increase, if parents and their families do not teach the skills normatively as applicable in the community.

In general, the result of the role of parents in training their activity of daily living skills is good. Although each subject still exists that is not optimal in carrying out activities in several aspects. However, if habituation and continuity of learning can be done with full sincerity, undoubtedly the ability of students with visual impairment in the skills of activity of daily living better will be achieved. So that they can be independent, more confident, empowered and can actualize himself optimally in the middle of society.

\section{References}

Santosa, Ayu Winda Utami dan Adijanti Marheni. (2013). Perbedaan Kemandirian Berdasarkan Tipe Pola Asuh Orang Tua pada Siswa SMP Negeri di Denpasar. Jurnal Psikologi Udayana, 54-62.

Dewi, Audy Ayu Arisha dan Tience Debora Valentina. (2013). Hubungan Kelekatan Orangtua-Remaja dengan Kemandirian pada Remaja di SMKN 1 Denpasar. Jurnal Psikologi Udayana, 181-189.

Dewanggi, Mustika, dkk. (2012). Pengasuhan Orang Tua dan Kemandirian Anak Usia 3-5 Tahun Berdasarkan Gender di Kampung Adat Urug. Jurnal Ilmu Keluarga dan Konseling, 19-28

Ladytia Ninis. (2016). Jurnal: Pelatihan Membuat Telur asin Terhadap Keterampilan Pravokasional anak Tunanetra. Jurusan Pendidikan Luar Biasa, Fakultas Ilmu Pendidikan, Universitas Negeri Surabaya.

Masna. (2013). Resiliensi Remaja Penyandang Tunanetra pada SLB Ruhui Rahayu di Samarinda. Journal Psikologi, FISIP Universitas Mulawarman, Kalimantan Timur.

Nixon, Sulis Mariyanti. (2012). Gambaran Kemandirian anak Penyandang autis yang Mengikuti Program Aktivitas Kehidupan Sehari-hari (AKS). Jurnal Psikologi Universitas Esa Unggul. Jakarta. 
Sastya Eka Pravitasari, M. Salih Soeaidy, dan Minto Hadi. (2014). Jurnal: Pemberdayaan bagi Penyandang Tunanetra guna Meningkatkan Kualitas Sumber daya Manusia. Jurusan Administrasi Publik, Fakultas Ilmu Administrasi, Universitas Brawijaya, Malang.

Arikunto, S. (2006). Prosedur Penelitian. Jakarta: Rineka Cipta.

Crews, Nicola J. (1992). Buku pegangan guru. Jakarta: Yayasan Pendidikan Dwituna Rawinala.

Moleong, L. J. (2006). Metodologi Penelitian Kualitatif. Bandung: PT. Remaja Rosdakarya.

Nasution, S. (1996). Metode Penelitian Naturalistik Kualitatif, Bandung: Tarsito.

Soemantri, Sutjihati. (2007). Psikologi Anak Luar Biasa. Bandung: Refika Aditama.

Setiyoko Puguh. (2015). Masa Pubertas Anak Tunanetra (skripsi). Jurusan Pendidikan Luar Biasa, Fakultas Ilmu Pendidikan, Universitas Negeri Surabaya.

Undang-undang Nomor 20 Tahun 2003, tentang Sistem Pendidikan Nasional, Jakarta: Depdiknas.

\section{Proceedings Papers:}

Kusumawardhani, dkk. (2010). Hubungan Kemandirian Dengan Adversity Intelligence Pada Remaja Tuna Daksa di Slb-D YPAC Surakarta. Proceeding Konferensi Nasional II Ikatan Psikologi Klinis, Himpsi, $252-257$.

\section{Copyrights}

Copyright for this article is retained by the author(s), with first publication rights granted to the journal.

This is an open-access article distributed under the terms and conditions of the Creative Commons Attribution license (http://creativecommons.org/licenses/by/4.0/). 